\author{
Леонід Зашкільняк / Leonid Zaszkilniak / Leonid Zashkilnyak \\ (Львівський національний університет ім. Івана Франка \\ Lwowski Narodowy Uniwersytet im. Iwana Franki) \\ https://orcid.org/0000-0003-0018-5095
}

\title{
Теоретичні проблеми сучасної історичної політики в Україні
}

\author{
Theoretical Problems of Current Historical Politics in Ukraine
}

\section{PЕЗЮME}

У статті розглянуто теоретичні проблеми сучасної історичної політики в Україні. На початку подано визначення історичної політики як інструменту державної влади для утвердження домінантних інтерпретацій минулого. Далі Автор аналізуе теоретичні питання соціальних функцій історичного знання і стверджує, що головною серед них є соціальна ідентифікація членів спільноти, яка прагне відокремитись від інших спільнот. Підкреслено, що історія виступає як «біографія» спільноти чи особи, а історичне знання - як твір ідеологів цієї спільноти. При цьому використано теорію «культурної імпутації» польського історика Войцеха Вжоска. Автор запроваджує також власну концепцію обмеженості історика у розумінні та поясненні минулого з сучасних позицій, оскільки біжучий стан пізнання має мождивість спиратися тільки на минулі взірці. Далі охарактеризовано труднощі сучасної української історіографії у формуванні «нормативного» образу України, який би передбачав проекцію суб'єктності сучасної держави у їі минуле. Українським історикам доводиться долати численні антиукраїнські міфи і стереотипи, вироблені впродовж століть сусідами України, насамперед Росією і Подьщею. В заключній частині статті подано приклади поступової переоцінки українськими істориками усталених і поширених стереотипів, зокрема щодо концепту «великої вітчизняної війни», а також проаналізовано заходи органів влади України щодо історичної політики після т.зв. революції гідності та початку російсько-української війни, зокрема щодо декомунізації і повернення до суспільного історичного дискурсу борців за незалежність України.

Ключові слова: історична політика, Україна, соціальні функції історії, українська історіографія, міфи і стереотипи 
Термін «історична політика» $є$ відносно новим як для Европи, так і для України ${ }^{1}$. Загалом його тлумачать як набір практик, 3 допомогою яких політичні сили, що утримують владу, використовують адміністративні і фінансові ресурси держави 3 метою утвердити в суспільстві як домінантні певні визначені інтерпретації історичних подій. Идеться про використання історії як інструменту формування суспільної свідомості. Критики цієї політики вважають, що ії реалізація пов' язана 3 політизацією історії і особливого прояву набула в посткомуністичних країнах Східної Європи, де гостро постало питання прискореного формування національних ідентичностей, котрі повинні були елімінувати зі свідомості населення елементи «комунізму» і «радянськості». Походження і механізми історичної подітики на сьогодні вивчаються багатьма дослідниками르. Використання історії в політико-ідеологічних цілях не є новиною і застосовувалося як серйозний аргумент 3 незапам' ятних часів у взаєминах між спільнотами, народами, державами.

Поле сучасних досліджень історичної політики є дуже широке і складне до охоплення. Якщо взяти найбільш сутнісні речі останньої чверті століття, то вони представдяються так: європейська цивілізаційна орієнтація на зближення народів, толерантність, мультикуль-

1 Термін «історична політика» (Geschichtspolitik) виник у Німеччині під час «битви істориків» 1980-1990-х р. у зв'язку з політикою «морально-політичного повороту» канцлера Г. Коля для окреслення дій, спрямованих на нав'язування суспільству певної версії історії. Потім він поширився у Польщі, набувши негативних конотацій в політиці правих сил країни. В Україні він залишається відносно новим і розглядаеться в дискурсі індивідуальної і колективної історичної пам'яті. Див.: Г. Касьянов, Історична політика 1990-х - початку XXI ст.: Україна і пострадянський простір, „Україна модерна" 2014, 21, s. 135-159.

2 Див.: А. Киридон, Гетеротопії пам'яті: теоретико-методологічні проблеми студій пам'яті, Київ 2016; Историческая политика в ХХІ веке: Сборник статей, под ред. А. Миллера, М. Аипмана, Москва 2012; нам теж доводилося торкатися цієї теми L. Zaszkilniak, Polityka tożsamości i pamięci na Ukrainie. Dyskusja, w: Pamięć i pytania o tożsamość. Polska. Ukraina, red. T. Horbowski, P. Kosiewski, Warszawa 2013, s. 42-43, 97-99; 1. Зашкільняк, Історична пам'ять та історіографія: методологічні аспекти взаємодії, „Національна та історична пам'ять”, Зб. наук. праць, Київ 2012, вип. 2, s. 218-234; idem, Історична пам'ять і соціальні функиії історії в сучасному світі, w: Iсторія - ментальність - ідентичність, вип. IV: Історична пам'sть українців і поляків у період формування національної свідомості в ХІХ - першій половині XX століття: колективна монографія, за ред. Л. Зашкільняка, Й. Пісуліньської, П. Серженги, Львів 2011, s. 21-26; idem, Залежна від політиків. Історична політика держави Украйна ніколи не ьрунтувалася на виключно українських підходах, „Український тиждень” 2010, 25-26, s. 40-41; L. Zaszkilniak, Nacjonalizacja historii: państwo i historiografia na wspótczesnej Ukrainie, w: Studia Interkulturowe Europy Środkowo-Wschodniej, t. 2, Warszawa 2008, s. 31-38. Треба також згадати численні праці Я. Грицака, Г. Касьянова, $\Lambda$. Нагорної, А. Портнова та інших. 
турність, глобалізацію явно увійшла в суперечність або й конфлікт 3 націоналізмом із його культом самобутності і окремішності й навіть нетолерантності по відношенню до інших народів і культур. Додатковим елементом вторгнення політики в історію та ії інструментального використання стало рішуче зростання ролі інформації та мождивостей іiі поширення («інформаційна революція»), яке відкриває небачені простори маніпуляції свідомістю людей. Історична політика характерна нині практично для всіх країн світу, оскільки уряди і державні установи не можуть стояти осторонь явищ культурної конфліктності, яка особливо загострилась в європейських країнах, котрі проводили курс на мультикультурадізм і міжнаціональну толерантність. Але особливо багатий конфліктний потенціал мають старі «історичні порахунки» між сусідами. Практично немає жодної країни в Европі, яка б не мала «старих» історичних ран зі своїми сусідами. Такі ситуації вже проаналізовано в багатьох виданнях, в тому числі знаній міжнародній праці “Европа та іiі болісні минувшини” (Автори і упорядники Жорж Мінк і Лора Неймаєр і Паскаль Баннар, 2009)3. А самі історичні проблеми вже стали об'єктом серйозного втручання міжнародних організацій, таких як ЮНЕСКО, Свропарламент, найрізноманітніші міжнародні і двосторонні комісії з шкільних підручників, свят тощо.

У фаховому середовищі істориків історична політика сприймається здебільшого критично. І автор цих заміток не раз критично висловлювався на адресу історичної політики в сучасній Україні, в тому числі й тої, яку проводив Український інститут національної пам'яті.

Проте в цьому нарисі прагнемо зупинитись на важдивому теоретичному питанні, а саме: чи взагалі потрібна політика пам'яті або історична політика в сучасному суспільстві як такому і якими ми бачимо стосунки між науковою та інструментальною історією (публічною історією). Інші питання історичної політики - такі як місця пам'яті, комеморативні практики, освіта, наука, інформаційна сфера - вимагали би значно роздогішої розмови.

Для відповіді на поставлені питання треба спочатку розібратись чим е історичні знання в широкому і науковому відношеннях. Найпростіша відповідь полягала би в тому, що вони є продуктом дюдського інтелекту в намаганні усвідомити себе в навколишньому світі, сформувати свою «біографію». Так само як і «біографію» інших людей та спільнот. Вивчення еволюції історіографії впродовж віків по-

з Європа та ї болісні минувщини, автори-упорядники Ж. Мінк і А. Неймаєр у співпраці з П. Баннаром, Київ 2009. 
казуе в основному зміну правил конструювання історичних знань на основі розширення інтелектуальних мождивостей людства. Але мета і сенс такого конструювання залишаються незмінними: пізнати себе через свою «біографію», тобто історію. В цьому і полягає сутність соціальної функції історії. Без неї немає ані особи, ані спільноти, ані науки. Ще одною функцією історії у новочасний період, яка частково зберігається донині, були спроби визначення майбутнього.

3 іншого боку, історію як історичні знання і соціальну пам'ять творять представники певної спільноти, а не абстрактні спільноти як такі. Вони конструюють історію на матеріалі та уявленнях передусім минулого, яке і витворило сучасну їм суспільну ситуацію. Назагал це речі добре знані, котрі польський історик Войцех Вжосек називає «культурною імпутацією» й «моделлю історичного мислення і дослідження» («imputacja kulturowa» $\mathrm{i}$ «model myślenia i badania historycznego») 3 цього виникає й завжди виникатиме кодізія між людським прагненням до кращого майбутнього і постійним шуканням його в минулому. Ця колізія неуникненна і неподоланна - просто одне минуле буде замінюватись іншим, але колізія залишатиметься. Так само, як залишатиметься вічна пізнавальна суперечність між пізнаним і пізнаваним (cognitive collision): пізнане вже не є тим, що представлене у знаHнi (perceived phenomenon is not that which is presented in knowledge). Історія як інструмент формування індивідуальної та соціальної свідомості задишатиметься вічним інструментом самоідентифікації осіб і спільнот. Але саме це ставить сувору вимогу дуже обережного обходження $з$ таким інструментом як історія, оскільки образи минулого є назагал поганим порадником для бачення сучасного i, тим більше, майбутнього. Історичні знання як колективна пам'ять є не тільки інструментом політики та ідеології, вони виконують цілком конкретні і зрозумілі легітимаційні завдання: «узаконюють» державність, націю, групові і спільнотні інтереси тощо. Навряд чи доцільно в цьому місці сперечатися про те - добре це чи погано. Так було, е і буде, оскільки такою є властивість людської свідомості в пошуку своєї ідентичності. Справа в іншому: хто, як і для чого використовуе історичне знання. Ось тут з'являеться площина для роздумів і сумнівів.

Таким чином, якщо підсумувати, то виходить, що історик є вільний у намірах реконструкції минулого і, водночас, не вільний в мождивостях його інтерпретації та репрезентації. Він обмежений всією сферою власного суспільно-культурного багажу, починаючи 3 мови і закінчуючи приналежністю до певної історичної школи чи спільно-

4 Див.: W. Wrzosek, O myśleniu historycznym, Bydgoszcz 2009. 
ти. А щодо майбутнього, то воно може конструюватись, як показав ще К. Поппер, як нескінченна множина альтернативних реалізацій сучасної ситуації.

Внесення кудьтурного чинника в історіописання розвертає його в інший бік - до ідеологічних в своїй сутності перспектив. Сучасні тенденції розвитку світової культури засвідчують, що історія (як подія) не є тим, що про неї пишуть історики (знання), а також не є самою минулою дійсністю; вона є дискурсом, специфічним способом вживання мови в публічній сфері, вона $є$ «культурною практикою осіб і спільнот». Тому можна підсумувати такими словами: намагання істориків звільнитися від примар минулого невблаганно провадять ïх до залежності від примар сьогодення. В цьому і подягає постійна «свобода несвободи» історика. І від неї немождиво втекти.

Зрозуміло, що фаховість історика полягає власне в усвідомленні своєї залежності від сучасності і вмінь використовувати наявний на сьогодні пізнавальний інструментарій для проникнення і пояснення минулого. При цьому провідну роль, на нашу думку, відіграє усвідомлення істориком суб'єктності об'єкта пізнання (каламбур!), тобто чіткого уявлення того явища, яке ми збираємось досліджувати. Коди ми говоримо про Україну чи українців, то повинні чітко усвідомлювати той факт - наскільки вони виступають суб'єктами пізнання чи об'єктами. I тут важдиво підкреслити, що будучи об'єктами пізнання, вони водночас можуть бути суб'єктами пізнання ддя тих дослідників, котрі інтерпретують їхню історію «зсередини», тобто як суб'єкти, в той час як для історика іншої суб'єктності (російського, польського британського тощо) минуле України й українців виступатиме як «Інше» й «Інакше». («Історія і є самопізнанням людиною самої себе»!)

3 цього випливає, що для українського історика основним культурним кодом («кудьтурною імпутацією») задишатиметься «суб'єктність» історії України. Наскільки така суб'єктність може долати суб'єктивність - залишається під питанням. Важдиво одне - конструюючи минуле свого «об'єктивного суб'єкта», історик свідомо чи несвідомо творить «біографію» цього суб'єкта, незалежно від того, чи торкається вона всієї різноманітності цього суб'єкта чи тільки його частини. Фактично ж - творить Себе.

Від кінця XX ст. українська історіографія переживає складний і неоднозначний період одночасного пошуку «власного обличчя» (суб'єктності) і «вписування в світове історіописання». Ці процеси не є простою справою, якщо подивитися на них з позиції тривалого у кілька століть - заперечення існування українського народу та його права на власну державність. Немає народу - немає історії: так при- 
наймні довгий час розповідади і переконували російська і польська історіографії та політики з погляду інтересів імперськості чи великодержавності. XX ст. не було сприятдивим для української ідеї. Драматичне перекроювання мап і держав під час двох світових війн не сприяли поширенню розголосу про українців і Україну, а усталені стереотипи перешкоджали і далі перешкоджають світові зрозуміти цих т.зв. «тіродьців Сходу». I коли всупереч різноманітним скептикам постала незалежна Україна, то далеко не всі зрозуміли що воно таке. Чимало спостерігачів говорили (а часом далі продовжують говорити), що Україна немає своєї «біографії» в сенсі історії, а є тільки «клапті» біографій Польщі, Литви, Росії та інших їі сусідів. Проте, українська історіографія вже давніше сконструювала свою модерну «біографію» (схема М. Грушевського), але поступалась в іiі поширенні своїм більш потужним в інтелектуальному просторі «державним» сусідам.

Цей процес конструювання «біографії» України вже неодноразово стояв в центрі наукових і публіцистичних дискусій, а література надічуе десятки, якщо не сотні публікацій ${ }^{5}$ Закордонні дослідники, які звертали увагу на еволюцію українського історіописання після відновлення Української державності, відзначали ії «експериментальний» характер, що відкриває сприятливі наукові перспективи в річищі сучасних новаторських течій, а також висловлювади певну стурбованість щодо тенденцій повернення до застарілих уявлень про історію та історичне пізнання під впливом певних суспільно-подітичних чинників 6 .

Дійсно, якщо уважно придивитися до розвитку історіографії в Україні за останні чверть століття, то можна побачити дві головні тенденції, що позначилися на іiі змістовному та методологічному характері. На загал, вони добре знані українським історикам і вже ба-

5 У цьому нарисі назвемо тільки деякі: Українська історіографія на зламі XX $і$ XXI століть: здобутки і проблеми, колективна монографія за ред. Л. Зашкільняка, Львів 2004; Н. Яковенко, Нариси кризової історіографії, „Критика”, Київ 2006, ч. 1-2; Т. Stryjek, Jakiej przeszłości potrzebuje przyszłość? Interpretacje dziejów narodowych w historiografii i debacie publicznej na Ukrainie 1991-2004, Warszawa 2007; А. Портнов, Упражнения с историей поукраински, Москва 2010; Л. Зашкільняк, Метаморфози сучасної Кліо (про нові тенденції світового історіописання на початку XXI столітmя), w: Theatrum Humanae Vitae. Cmydii на пошану Наталі Яковенко, Київ 2012 та ін.

6 Американський вчений Марк фон Гаген зауважував: «Україна являє собою приклад національної культури з надзвичайно прозорими межами, але саме той приклад, який можливо відповідає постмодерному політичному розвиткові, де донаціональні, наднаціональні і міжнаціональні процеси вимагають такої ж уваги істориків, суспільствознавців та "культурологів", як і процеси, які раніше вивчалися у вигляді національних...» M. von Hagen, Does Ukraine Have a History?, „Slavic Review” 1995, 3, s. 670 . 
гато раз обговорювалися в науковій літературі. Перша - прагнення розвіяти численні фальсифікації і спотворення минулого українців та України, що нагромадились за століття їх колоніального статусу в складі різних імперій, а, насамперед, під час існування СРСР, i, як наслідок - сконструювати національний «канон» історії, який би служив формуванню національно-державної суспільної свідомості та соціальної пам'яті. Друга тенденція - опанування здобутків світової історичної думки та їі застосування в історичних дослідженнях з метою подолання відставання українського історичного знання та історичноінформаційного простору від світових взірців ${ }^{7}$. Багатьом фаховим історикам ці тенденції видаються взаємно суперечливими за аналогією 3 дихотомією «ідеологія-наука». Тому мождивість звільнення від догм радянського «марксизму-ленінізму» українські пострадянські історики сприйняли переважно, як заміну «комуністичної ідеології» - «безідеологічними стандартами» (позитивізм) або «національним дискурсом» (націоналізм).

3 огляду на значний обсяг «радянізації» суспільної свідомості в незалежній Україні, відповіддю на суспільні виклики стала «націоналізація» ii минулого (так це назвав Георгій Касьянов) $)^{8}$. Здавалося, що такий підхід до минулого є цілком обгрунтований і закономірний. Однак для української історії це обернулося двома загалом несприятливими наслідками, характерними для абсодютизації минулого як бази для прогнозування майбутнього: по-перше, за підставу «націоналізації» було взято взірці початку XX ст., а не ії кінця, а саме - схеми М. Грушевського й В. Аипинського. Запропонована i, зрештою, нині реалізована версія «нормативної» історії України, або її «канон», мало чим різняться від «марксистсько-ленінського» погляду на минуле України та українців; ім властиві всі провідні риси, які ми знаходимо і у Гегеля і у Маркса і в радянській історіографії.

Діагноз такого стану речей в «історії з історіографією» було поставлено вже з десяток років тому, коли відзначиди мождивість поєднання суспільних завдань і очікувань від історичного знання та його функцій 3 науковими параметрами самого цього знання. Як писала знаний історик Наталя Яковенко, криза сучасної пострадянської історіографії не є кризою науки, а є кризою «ідентичності історика», кризою вичерпання макросоціальних схем історичного процесу, котрі вже давно не задовольняють науку і науковців 9

7 Українська історіографія, s. 24-56.

8 Термін «націоналізація» історії запропонував Г. Касьянов. Ibidem, s. 57-73.

9 Н. Яковенко, op. cit., s. 23. 
Якщо ми подивимось на здобутки сучасної української історіографії у порівнянні з іншими історіографіями, то побачимо значний поступ в вивченні «білих і чорних плям» історії, але, водночас, маємо цілу низку «проваль», котрі, м'яко кажучи, не сприяють формуванню цілісного образу «історичної України» як суб'єкту цивілізаційного процесу. Це торкається всіх періодів минулого України та українців - від Давньої Русі й до сучасної Української держави. Надалі як в Україні, так і на світовій арені продовжують функціонувати і поширюватися міфи і стереотипи, створені великодержавними ідеодогами попередніх імперських часів, а також і сучасними неоімперськими епігонами. Суб'єктність України як чинника європейського та світового історичного процесу губиться в хитросплетінні цих стереотипів. Про шкоду такої ситуації для самих українців, а також авторитету їх державності на міжнародній арені годі говорити. Тому й не випадковими виглядають сумніви частини європейських обивателів, а навіть фахових істориків, у «історичній правомірності» існування українців та України.

Усвідомлюючи небезпеку прямолінійної «націоналізації» української історії, яка слушно піддається критиці, наважимося запропонувати новий шлях і термінологію для осмислення минулого України. Сучасний стан свідомості багатьох громадян української держави, не кажучи про представників інших народів, в тому числі на Заході, задишається в полоні російських, а часом і польських стереотипів про Україну і українців як про «неповноцінну» націю, «клапті» політичних націй російської, польської чи радянської. Фактично йдеться про наслідки тривалого колоніального становища як етносу, так і території України в складі сусідніх держав (не буду зараз вдаватись у визначення «колоніального стану» $\left.{ }^{10}\right)$. Стан суспільної свідомості і соціальної пам'яті багатьох українців $є$ наскрізь «постколоніальний», тобто суміш російських, радянських світоглядних уявлень і образів. Про вплив цих стереотипів свідчать численні соціологічні опитування. Подам дише кілька фактів з опитування, проведеного влітку 2015 р. спільно кількома авторитетними українськими та зарубіжними соціологічними службами на території всієї України, але без окупованих Росією земель (після року боротьби з російською агресією!) щодо ро-

10 Про це я писав в: Л. Зашкільняк, Радянські історичні міфи в сучасній українській історіографії: «старе вино в нових міхах», w: Світло й тіні української радянської історіографії. Матеріали міжнародної наукової конферениій (Київ, Україна, 22-23 травня 2013 р.), за ред. В.А. Смолія, Київ 2015, s. 17-31; idem, Радянські міфи в сучасній украйнській історіограбї̈: час змін і замін, „Історія та історіографія в Европі”, вип. 5: Украӥна в ХX-ХХІ століттях: на шляху гідності і свободи, Київ 2016, s. 103-117. 
зуміння і ставлення до подій української історії. Результати дуже сумні: 42,9\% респондентів вважають Київську Русь державою трьох «братніх» народів - українців, росіян і білорусів і тільки 27,9\% - державним утворенням українців; 38,6\% опитаних позитивно оцінили Подтавську битву і поразку гетьмана Івана Мазепи і лише $17 \%$ оцінили їі негативно; 45,2\% позитивно оцінили утворення в Харкові в 1917 р. УСРР; а в першу десятку видатних історичних діячів України увійшли Петро I (6. позиція), Сталін (10. позиція) ${ }^{11}$. Можна говорити про провал переформатування соціальної пам'яті. Тому, на мою думку, перед українськими істориками стоїть нині складне завдання не «націоналізації», а «деколонізації» української історії.

Зрозуміло, що про ключові моменти такої деколонізації треба говорити дуже багато. У цьому нарисі обмежимось загальною пропозицією і кількома провідними «провалдями» в українській національній історії, котрі вимагають серйозного методологічного і конкретно-історичного переосмислення.

Перше. Українське суспільство потребує сьогодні наукової академічної історії України. Не багатотомної, а багатосенсовної. Дискусія щодо появи такого синтезу активно ведеться від 2012 р. на сторінках „Українського історичного журналу” й на низці семінарів та конференцій ${ }^{12}$. Можна погодитись 3 провідними авторами дискусії Г. Касьяновим і О. Тодочком, котрі пропонують представити історію України не лише як історію конкуренції і змагань різних станів, верств, конфесій, етносів, культур, націй, держав тощо, а і як простір взаємодії, взаємопроникнення, взаємозбагачення цивілізацій, культур, народів ${ }^{13}$. За таких умов йдеться про історію «території», яку займає сучасна Україна, про цивілізаційну еволюцію народів, що ії населяли. Проте, виникає дуже серйозне застереження - чи йдеться про Україну, чи про якийсь незрозумілий конгломерат народів і культур, «прохідний двір» Европи. Зрозуміло, що ідентифікаційний, легітимаційний аспекти такої історії можуть мати не стільки конструктивний, скільки деструктивний характер у формуванні суспільної свідомості з усіма наслідками, які з цього випливають. Тому треба погодитись із слушним зауваженням Олега Горенка, висловленим ним під час

11 Україна. Результати соиіологічного дослідження, проведеного у рамках проекту «Започаткування Національного діалогу в Украйні» січень-червень 2015, Київ 2015, s. 29-32.

12 Див.: Г.В. Касьянов, О.П. Толочко, Національні історї та сучасна історіографія: виклики і небезпеки при написанні нової історії Украйни, „Український історичний журнал" 2012, 6, s. 4-24, а також статті інших істориків на сторінках „Український історичний журнал" 2013-2015 pp.

13 Ibidem, s. 21. 
дискусії: «Історик має пам'ятати ще й те, що наратив у чималій мірі творить июдину, яка робить себе, щосили намагається “зробити" інших, і аж ніяк не схильна відмовдятися від найменшої нагоди "робити історію"» ${ }^{14}$.

На мою думку, важдиво підкреслити, що такий синтез, як «біографія» України, повинен виходити з суб'єктності сучасної держави і політичної нації, але, водночас, бути історією людей та їхніх соціальних утворень на території сучасної України. Це не повинна бути історія державності чи етносу, оскільки вони є лише продуктом соціальної комунікації людей, продуктом, котрий повсякчасно змінюється і надалі буде змінюватись. Проте, український гранд-наратив все одно повинен бути і буде історією України як суб'єкта, а не тільки історією об'єкта. Очевидно, що це накладає на істориків певні ідеологічні обмеження. Цього не треба боятись, тому що, як слушно зауважив мексикансько-американський історик Карлос Рохас, історія безумовно е включенням в неї сучасного, вона насичена ідеологією $i$ соціальним замовленням. Історики змушені займати визначену ідеологічну та суспільну позицію, і ця позиція визначає межі можливого використання отриманих результатів, тому праця історика завжди несе в собі ідеологічні ризики ${ }^{15}$.

За таких умов всі форми суспільного життя на території сучасної України повинні бути «українськими» за визначенням, треба переглянуті всі періоди і «провалдя» цієї історії з погляду сучасного суб'єкта - України. Йдеться про давню Русь, монголо-татарський період, подьсько-литовський період, козацькі часи, модерні проекти, державницькі змагання XX ст. По кожному з них ми маємо велику кількість стереотипів і міфів, що виникли в попередні часи не в українській історіографії і значною мірою продовжують функціонувати в сучасній українській історіографії. Особливо докладно ці міфи і стереотипи розглянуто у фундаментальному тритомнику Украйна $i$ Росія в історичній ретроспективі, більшість висновкових положень якого все ще, на жаль, не отримали поширення в сучасній українській історіографії ${ }^{16}$. Щодо багатоманітної системи міфів і стереотипів, які

14 О.М. Горенко, Украйнський метанаратив в епоху пропаганди, „Український історичний журнал" 2014, 2, s. 9.

15 К.А.А. Рохас, Историография в 20 веке. История и историки между 1848 и 2025 годами, Москва 2008, s. 113.

16 В.Ф. Верстюк, В.М. Горобець, О.П. Толочко, Украйнські проекти в російській імперії / Україна і Росія в історичній ретроспективі. Нариси в 3-х томах, т. 1, Київ 2004; В.А. Гриневич, В.М. Даниленко, С.В. Кульчицький, О.Є. Аисенко, Радянський проект для України / Україна і Росія в історичній ретроспективі. Нариси в 3-х томах, т. 2, Київ 
перейшли в сучасність від Російської імперії, написано чимало: від ідеї «триєдиної» руської нації та українсько-російської спорідненості до міфу про особливу історичну місію росіян об'єднати всіх слов'ян і православних. Про це дуже переконливо писав у дев'яностих роках XX ст. російський вчений Євгеній Анісімов в статті Исторические корни илперского мышления в России (1996) та багато інших дослідників ${ }^{17}$.

Наведу як приклад тільки низку радянських міфів про Другу світову війну, яка задишається головним (і чи не останнім) ідеологічним інструментом сучасної російської пропаганди, спрямованої на розпад і ліквідацію української державності. Фундаментальний радянський міф, котрий донині залишається стрижневим компонентом ідеологічного колоніалізму щодо України, є міф «Великої Вітчизняної війни» $\mathrm{i}$ «великої Перемоги». Історія виникнення цього міфу та його інструментального характеру в останніх десятиліттях існування СРСР добре висвітлена в сучасній історіографії. Цей комуністичний конструкт в комплексі з набором його складових про «подвиг радянського народу у Великій Вітчизняній війні», «вирішальною роллю комуністичної партії, «морадьно-політичною єдністю радянського народу», «потужним партизанським рухом в тилу ворога», «зрадниками і колаборантами» та багатьма іншими й сьогодні вірно служить обгрунтуванню існування імперської Росії та ії колоній під виглядом СРСР і радянського народу. Цей міф однозначно спрямований на заперечення українського виміру війни, оскільки не залишає місця для українського інтересу, незважаючи на химерні спроби деяких істориків послатися на творення українських міністерств, на участь УРСР в заснуванні ООН тощо.

Сьогодні в світовій та українській історіографії нагромаджено велику кількість фактографічного матеріалу, який заперечує радянську версію «великої вітчизняної війни», яка не була «вітчизняною» для багатьох народів СРСР, в тому числі багатьох українців, котрі інакше трактувади саме поняття «вітчизна». Одним $з$ останніх видань, в яких зроблена грунтовна спроба осмислення «української війни» під час Другої світової, є двотомне видання Інституту історії України НАН України історичних нарисів “Україна в Другій світовій війні: погляд з XXI століття"18. Фактично вперше в українській історіогра-

2004; С.В. Кульчицький, Б.О. Парахонський, Новітній украйнський державотворчий проиес / Украйна і Росія в історичній ретроспективі. Нариси в 3-х томах, т. 3, Київ 2004.

17 Е.В. Анисимов, Исторические корни имперского мышиления в России, http://src-h. slav.hokudai.ac.jp/sympo/Proceed97/Anisimov.html [dostęp: 30 IX 2018].

18 Украйна в другій світовій війні: погляд з ХХІ ст. Історичні нариси. У двох книгах, кн. 1-2, Київ 2011. 
фії у ньому обгрунтовано терміни «друга світова війна» і «німецькорадянська війна», стверджується, що всю різноманітність подітичних і воєнних подій світової війни «з наукових позицій некоректно трактувати в руслі поняття «Велика Вітчизняна війна» ${ }^{19}$. А вміщені у двох книгах аналітичні матеріали показують значно ширший спектр настроїв, сподівань і дій українців під час війни та окупації, ніж це підпадає під ідеологему «Великої Вітчизняної війни». Розкриваючи все нові і нові документадьні матеріали, можна стверджувати словами Владислава Гриневича, що «для значної частини українського населення "сталінське визволення від німців", немов у дзеркальному відображенні, повторювало картину “гітлерівського “звільнення України від більшовиків" - звільнення без визволення ${ }^{20}$. До речі, так само гостро критично оцінив радянський концепт війни і перемоги знаний російський історик Юрій Афанасьєв: «Для Сталіна та його оточення, коли вони визнали обстановку хоча б мінімально вигідною для себе, традиційні імперські цілі царської Росії перевтілились в революційні цілі СРСР і вони одразу приступили до їх реалізації. Ні до оборонної, ні до визвольної війни ці цілі відношення не мали» ${ }^{21}$.

Але головне полягає в тому, що радянський міфологізований підхід до світової війни не залишає місця для третього суб'єкта, третьої сторони - українського та інших народів цього регіону континенту. Де ж тоді шукати_український націонадьний інтерес? Відповідь на це питання спробував дати Іван Патриляк у статті Між двома проваллями: Україна в роки Другої світової війни і ми підтримуемо запропоновані ним тези. Зокрема, йдеться про таке: остання війна була намаганням зберегти світ, усталений після Першої світової війни, зміцнити контроль великих держав над ресурсами і ринками, де західні держави використали тоталітарний СРСР проти тоталітарної ж Німеччини та її союзників, що призвело до поневолення України та низки країн Центральної Європи; поразка українського та інших національновизвольних рухів народів Центральної Європи в роки війни створила ситуацію «незавершеної» війни, яка повинна була закінчитися з крахом не тільки Німеччини, а й СРСР, але зіткнулася зі спробою Росії відновити контродь над пострадянським простором; тому, можна сказати, що «незавершена війна» ще продовжується i, мождиво, за-

19 Ibidem, кн. 1, s. 20.

20 В. Гриневич, Між молотом і ковадлом, „Український тиждень” 2013, 6, s. 38. Див. також добірку статей і матеріалів в цьому ж номері часопису під рубрикою “Звільнення від Бухенвальда таборами Гулагу".

21 Ю. Афанасьев, Другая война. История и память, http://www.yuri-afanasiev.ru/ articles/art_1996_59.htm [dostęp: 30 IX 2018]. 
вершиться з розпадом такого штучного імперського утворення, яким є сучасна Росія. Тому не можна вважати Україну як суб'єкта одним 3 переможців Другої світової війни - вона швидше є серед «переможених», оскільки національний інтерес України не був реалізований після закінчення воєнних дій, і вона опинилася під пресом російськобільшовицьких окупантів 22 .

Таким чином, історична політика зобов'язана дбати про легітимацію сучасного стану, значить, обгрунтовувати суб'єктність сучасної української держави, формувати сучасну українську політичну націю. Проблема полягає в тому, що впродовж багатьох століть українці були під потужним впливом інших держав та націй, для яких Україна була полем колонізації та асиміляції. I тут життево необхідний союз науки і культури, щоб конструйований образ не впадав в крайності етнічного націоналізму, але й не потурав збереженню застарілих, ворожих Україні стереотипів. Проблемним залишається питання поєднання науково-історичного знання з формуванням нових усталених образів (стереотипів) суб'єктної України. На жаль, тут поки що спостерігається спрощений, а часом і антинауковий підхід до пояснення минулого. Так було з історичною політикою під час президентства В. Ющенка, який надав пріоритет архаїчним оцінкам минулого України, переважно, козаччини, а також націоналістичного руху, які не вирізнядись науковістю. Тільки щодо оцінки Гододомору 1932-1933 рр. вдалося досягти помітного успіху. За президентства В. Януковича відбувся відкат до радянських міфів і стереотипів.

В останні роки, після т.зв. Революції Гідності 2013-2014 рр. і наступної російсько-української війни активність державних органів влади i, зокрема, Українського інституту національної пам'яті (УІНП) скерована на послідовну і рішучу декомунізацію суспільного дискурсу та впровадження в нього українського національно-визвольного руху XX ст. Пакет декомунізаційних законів, прийнятих Верховною Радою України в 2016 р., фактично заборонив частині населення, що підтримує «радянсько-ностальгійний» наратив, виражати свою ідентичність. Інший закон - «Про правовий статус та вшанування пам'яті борців за незалежність України у XX столітті» - серед іншого запроваджуе в суспільний обіг український національно-визвольний рух та його представників ОУН, УПА та інші радикальні організації. Цей закон та інші акти пам'ятєвої політики викдикади неоднозначну реакцію як всере-

22 І.К. Патриляк, Між двома проваллями: Украӥна в роки, Другої світової війни, „Проблеми всесвітньої історії" 2016, 1, s. 169-182. Див. також: Війна і міф. Невідома Друга світова, за заг. ред. О. Зінченка, В. Вятровича, М. Майорова, Харків 2016. 
дині країни, так, здебільшого і в сусідніх країнах. Не беручись в цьому місці оцінювати історичну роль національно-визвольного руху, зауважу, що він е складовою частиною української «біографії» і має повне право бути присутнім в історичному дискурсі. Важдиво надати йому науковий характер, який би відзначав його героїчні і негативні сторони. Але борці за українську незалежність не можуть бути ігноровані в суспільстві, яке цю незалежність реалізуе. А поширені і підтримувані, в тому числі з-за кордону, стереотипи щодо українського національно-визводьного руху як «антиукраїнського руху» (!?) мусять бути остаточно зруйновані і усунуті з суспільного обігу.

На сучасну історичну політику української влади безперечно накладається російська агресія в Україні та російсько-українська війна за незалежність і територіальну цілісність. Вона явно зменшуе багатоколірність сприйняття сучасного і минулого, проектує сучасне на минуле і спонукає радикалізацію та диференціацію суспільної думки. В цих складних воєнних умовах важливо втриматись на рівні виваженого аналізу ситуації та проведення науково обгрунтованої історичної політики, яка поєднуватиме державний патріотизм і здобутки наукового аналізу історії.

\section{BIBLIOGRAFIA (REFERENCES)}

Afanas'ev Yu., Drugaya vojna. Istoriya i pamyat', http://www.yuri-afanasiev.ru/articles/ art_1996_59.htm [dostęp: 30 IX 2018].

Anisimov E. V., Istoricheskie korni imperskogo mushleniya v Rossii, http://src-h.slav.hokudai. ac.jp/sympo/Proceed97/Anisimov.html [dostęp: 30 IX 2018].

Gorenko O.M., Ukraïns'kyj metanarativ v epokhu propagandy, „Ukraïns'kyj istorychnyj zhurnal" 2014, 2.

Grynevich V., Mizh molotom i kovadlom, „Ukraïns'kyj tyzhden” 2013, 6.

Grynevich V.A., Danilenko V.M., Kul'chic'kyj S.V., Lisenko O.Ye, Radyans'kyj projekt dlya Ukraïny w: Ukraïna i Rosiya v istorychnij retrospektyvi. Narysy v 3-kh tomakh, t. 2, Kyïv 2004.

Hagen M. Von, Does Ukraine Have a History?, „Slavic Review” 1995, 3.

Istoricheskaya polityka v XXI veke: Sbornik statej, red. A. Miller, M. Lipman, Moskva 2012.

Kas'yanov G., Istorychna polityka 1889-kh - pochatku XXI st.: Ukraïna i postradyans'kyj prostir, „Ukraïna moderna” 2014, 21.

Kas'yanov G.V., Tolochko O.P., Natsional'ni istorii ta suchasna istoriografiya: vyklyky i nebezpeky pry napysanni novoï istoriï Ukrä̈ny, „Ukraïns'kyj istorychnyj zhurnal” 2012, 6.

Kul'chyts'kyj S.V., Parakhons'kyj B.O., Novitnij ukraïns'kyj derzhavotvorchyj protses, w: Ukraïna i Rosiya v istorychnij retrospektyvi. Narysy v 3-kh tomakh, t. 3, Kyïv 2004.

Kyrydon A., Geterotopii pam'yati: teoretyko-metodologichni problemy studij pam'yati, Kyïv 2016.

Patrylyak I.K., Mizh dwoma provallyamy: Ukraïna v roky Drugoï svitovoï vijny, „Problemy vsesvitn'oï istoriï" 2016, 1.

Portonov A., Uprazhneniya s istoriej po-ukrainski, Moskva 2010.

Rokhas K.A.A., Istorriografiya v 20 veke. Istoriya i istoriki mezhdu 1848 i 2025 godami, Moskva 2008. 
Stryjek T. Jakiej przeszłości potrzebuje przyszłość? Interpretacje dziejów narodowych w historiografii i debacie publicznej na Ukrainie 1991-2004, Warszawa 2007.

Ukraïna. Rezul'taty sotsiologichnogo doslidzhennya, provedenogo u ramkakh projektu «Zapochatkuvannya Natsional'nogo dialogu v Ukrä̈ni» sichen'-cherven' 2015, Kyïv 2015.

Ukraïna $v$ drugij svitovij vijni: poglyad z XXI st. Istorychni narysy. U dvokh knigakh, kn. 1-2, Kyïv 2011.

Ukraïns'ka istoriografiya na zlami XX i XXI stolir': zdobutky i problemy, Kolektyvna monografiya za red. L. Zashkil'nyaka, L'viv 2004.

Verstyuk V.F., Gorobets' V.M., Tolochko O.P., Ukraïns'ki proekti v rosijs'kij imperï̈ w: Ukraïna $i$ Rosiya v istorychnij retrospektyvi. Narysy v 3-kh tomakh, t. 1, Kyïv 2004.

Vijna i mif. Nevidoma Druga svitova, za zag. red. O. Zinchenka, V. V'yatrovycha, M. Majorova, Kharkiv 2016.

Wrzosek W., O myśleniu historycznym, Bydgoszcz 2009.

Yakovenko N., Narysy kryzovoï istoriografii, „Krytyka” 2006, vol. 1-2.

Yevropa ta ï bolisni minuvshyny, avtory-uporyadnyky Zh. Mink i L. Nejmayer u spivpratsi z P. Bannarom, Kyïv 2009.

Zashkil'nyak L., Istorychna pam'yat' i sotsial'ni funktsiï v suchasnomu sviti, w: Istoriya - mental'nist' - identychnist', vyp. IV: Istorychna pam'yat' ukraïntsiv i polyakiv u period formuvannya natsional'noï svidomosti $v$ XIX-pershij polovyni XX stolittya: kolektyona monografiya, za red. L. Zashkil'nyaka, J. Pisulin's'koï, P. Syerzhengy, L'viv 2011.

Zashkil'nyak L., Istorychna pam'yat' ta istoriografiya: metodologichni aspekty vzayemodiï, „Natsional'na ta istorychna pam'yat'”, Zb. nauk. prats', Kyïv 2012, vyp. 2.

Zashkil'nyak L., Metamorfozy suchasnoï Klio (pro novi tendentsiï svitovogo istoriopysannya na pochatku XXI stolittya), w: Theatrum Humanae Vitae. Studii na poshanu Natali Yakovenko, Kyïv 2012.

Zashkil'nyak L., Radyans'ki istorychni mify v suchasnij ukraïns'kij istoriografii: «stare vino v novykh mikhakh», w: Svitlo j tini ukraïns'koï radyans'koï istoriografiï. Materialy mizhnarodnoï naukovoï konferentsii (Kyï, Ukraïna, 22-23 travnya 2013 r.), za red. V.A. Smoliya, Kyïv 2015.

Zashkil'nyak L., Radyans'ki mify $v$ suchasnij ukraïns'kij istoriografiï: chas zmin i zamin, "Istoriya ta istoriografiya $\mathrm{v}$ Yevropi", vyp. 5: Ukraïna $v$ XX-XXI stolittyakh: na shlyakhu gibnosti i svobody, Kyïv 2016.

Zaszkilniak L., Nacjonalizacja historii: państwo i historiografia na wspótczesnej Ukrainie, w: Studia Interkulturowe Europy Środkowo-Wschodniej, t. 2, Warszawa 2008.

Zaszkilniak L., Polityka tożsamości i pamięci na Ukrainie. Dyskusja, w: Pamięć i pytania o tożsamość. Polska. Ukraina, red. T. Horbowski, P. Kosiewski, Warszawa 2013.

\section{ABSTRACT}

The article deals with the theoretical problems of current historical politics in Ukraine. The beginning presents the definition of historical politics as an instrument of state power that works to confirm the dominant interpretations of the past. The author then analyses the theoretical issues relevant to the social functions of historical knowledge and argues that the principal one among them is the social identification of members of the community which seeks to separate itself from other communities. It is emphasised that history acts as a "biography" of a community or person, and historical knowledge functions as a product of the ideologists of this community. The argument references the theory of "cultural imputation" elaborated in detail by the Polish historian Wojciech Wrzosek. The author also introduces his own concept of the historian's limitations in understanding and explaining the past from contemporary positions, since the current state of knowledge has 
the ability to rely only on the past models. The subsequent part describes the difficulties of modern Ukrainian historiography in shaping the "normative" image of Ukraine, which would foresee a projection of the subjectivity of the modern state in its past. Ukrainian historians have to cope with numerous anti-Ukrainian myths and stereotypes that have been developed over the centuries by powerful Ukraine's neighbors, primarily Russia and Poland. The final part of the article provides examples of a gradual re-evaluation by Ukrainian historians of established and widespread stereotypes, in particular on the concept of "Great Patriotic War", and also analyses the measures taken by the Ukrainian authorities regarding historical policy after the so-called The Revolution of Dignity and the beginning of the Russian-Ukrainian War, in particular regarding de-communization and the return of the fighters for the independence of Ukraine to the social historical discourse.

Key words: historical politics, Ukraine, social functions of history, Ukrainian historiography, myths and stereotypes

\section{Teoretyczne problemy współczesnej historycznej polityki na Ukrainie}

\section{STRESZCZENIE}

W artykule rozpatrzono teoretyczne zagadnienia współczesnej polityki historycznej na Ukrainie. Najpierw podano określenie historycznej polityki jako instrumentu władzy państwowej dla poszerzenia i utwierdzenia dominujących interpretacji przeszłości. Następnie zanalizowano teoretyczne kwestie społecznych funkcji wiedzy historycznej i stwierdzono, że najważniejszą z nich jest społeczna tożsamość członków wspólnoty, która pragnie oddzielić się od innych wspólnot. Podkreślono, że historia występuje jako „biografia” wspólnoty lub osoby, a wiedza historyczna jako utwór ideologów tej wspólnoty. Przy tym wykorzystano teorię imputacji kulturowej polskiego historyka Wojciecha Wrzoska. Autor wprowadza też własną koncepcję ograniczeń historyka w rozumieniu i wyjaśnianiu przeszłości z pozycji współczesności w związku z tym, że bieżący stan poznawania stwarza możliwość oparcia się tylko na minionych wzorcach. W dalszej części scharakteryzowano trudności współczesnej ukraińskiej historiografii w kształtowaniu „normatywnego” obrazu Ukrainy, który przewidywałby projekcję przedmiotowości współczesnego państwa w jego przeszłość. Ukraińscy historycy muszą pokonywać wiele antyukraińskich mitów i stereotypów wytworzonych w ciągu stuleci przez sąsiadów Ukrainy, przede wszystkim Rosję i Polskę. Na końcu podano przykłady stopniowego obalenia przez ukraińskich badaczy ustalonych i poszerzonych historycznych stereotypów, zwłaszcza odnoszących się do konceptu „wielkiej wojny ojczyźnianej” oraz przeanalizowano przedsięwzięcia organów władzy Ukrainy w sprawie prowadzenia polityki historycznej po tzw. rewolucji godności i początku wojny rosyjsko-ukraińskiej, a zwłaszcza te związane z dekomunizacją i przywróceniem do społecznego historycznego dyskursu wojowników o niepodległość Ukrainy.

Słowa kluczowe: polityka historyczna, Ukraina, społeczne funkcje historii, ukraińska historiografia, mity i stereotypy 


\section{NOTA O AUTORZE}

Leonid Zaszkilniak - profesor doktor habilitowany, kierownik Katedry Historii Europy Centralnej i Wschodniej Lwowskiego Narodowego Uniwersytetu im. Iwana Franki. Bada nową i najnowszą historię Polski oraz krajów Europy Śródkowo-Wschodniej, polską i światową historiografię. Autor i współautor wielu publikacji, w tym syntez: Wstup do metodologii istorii (Lwiw 1996); Metodologia historii wid dawnyny do suczasnosti (Lwiw 1999); Istorija Centralno-Schidnoji Jewropy (Lwiw 2001); Istorija Polszczi: wid najdawniszych czasiw do naszych dniw (Lwiw 2002); Suczasna switowa istoriografija (Lwiw 2007); współkierownik i współredaktor wydawniczych serii Wielokulturowe historyczne środowisko Lwowa w XIXXX wieku (t. 1-5, Rzeszów 2001-2007); Historia - mentalność - tożsamość (t. 1-5, Rzeszów 2008-2013); Złota księga historiografii lwowskiej w XIX-XX wieku (t. 1-2, Rzeszów 2007-2013); Historia w Uniwersytecie Lwowskim. Badania i nauczanie (do 1939 roku) (Rzeszów 2016). Członek Narodowego Komitetu Historyków Ukrainy, Ukraińskiego Towarzystwa Historycznego, Towarzystwa Historiograficznego oraz wielu redakcji historycznych czasopism na Ukrainie i w Polsce. Laureat nagród: Nagrody „Przeglądu Wschodniego” (2003), Nagrody Pojednania Kapituły Polsko-Ukraińskiego Pojednania (2015), Państwowej Nagrody Ukrainy w Dziedzinie Nauki i Techniki (2017). E-mail: leoza10@gmail.com 